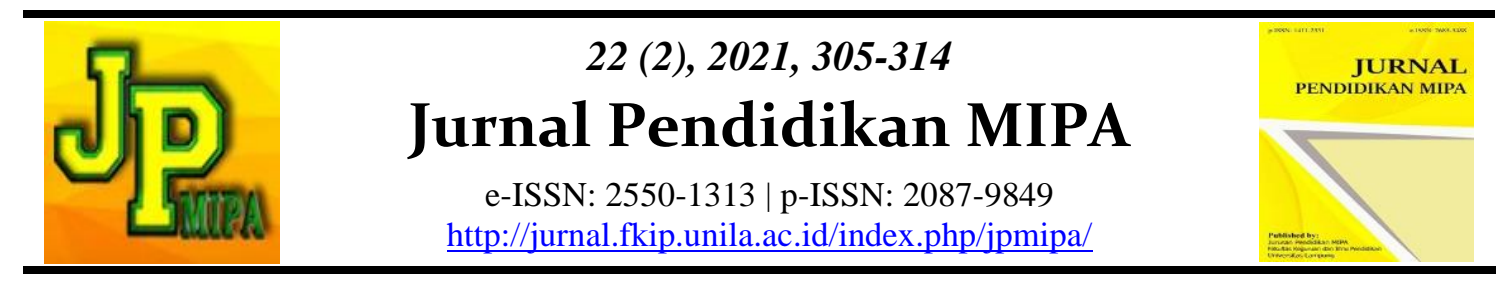

\title{
Critical Thinking Analysis of Junior High School Students on Temperature Topic during Virtual Learning
}

\author{
Aji Solehudin*, Riandi, Arif Hidayat, Sumar Hendayana \\ Department of Science Education, Universitas Pendidikan Indonesia, Indonesia.
}

\begin{abstract}
This article aims to analyze students' critical thinking skills of temperature topic through virtual learning at junior high schools. The method used in this research was descriptive qualitative with a case study approach. This research was conducted at seventh grade of the junior high school in Bandung, West Java. The instruments used is observation. The collected data were analyzed using Transcript Based Lesson Analysis (TBLA) to analyze student's dialogue. The results indicated that two out of the twelve indicators of critical thinking skills during virtual learning were developed. The two indicators are focusing on questions and the second is asking and answering questions. The low achievement of students' critical thinking skills is due to the limited time on virtual learning. Which is limited, so that teachers often apply learning method through transferring knowledge. Analysis of student activities and dialogue during virtual learning can be a source of teacher's reflection for making further improvement.
\end{abstract}

Keywords: critical thinking skill, temperature topic, virtual learning.

Abstrak: Artikel ini bertujuan untuk menganalisis kemampuan berpikir kritis siswa dalam pembelajaran virtual pada materi suhu di SMP. Metode yang digunakan dalam penelitian ini adalah deskriptif kualitatif dengan pendekatan studi kasus. Penelitian ini dilaksanakan di salah satu SMP di Kabupaten Bandung Jawa Barat dengan peserta siswa kelas VII. Instrumen yang digunakan yaitu observasi. Data yang terkumpul dianalisis dengan menggunakan Transcript Based Lesson Analysis (TBLA). Hasil penelitian menunjukkan bahwa dua dari dua belas indikator keterampilan berpikir kritis selama pembelajaran virtual terlihat. Kedua indikator tersebut yaitu memfokuskan pertanyaan dan bertanya dan menjawab pertanyaan. Rendahnya ketercapaian indikator keterampilan berpikir kritis siswa disebabkan karena keterbatasan waktu pembelajaran virtual yang terbatas sehingga guru seringkali menerapkan pembelajaran berupa transfer ilmu dari guru ke siswa saja. Analisis aktivitas serta dialog saat pembelajaran virtual juga dapat digunakan sebagai bahan refleksi bagi guru untuk melakukan evaluasi serta perbaikan pada pembelajaran selanjutnya agar lebih baik.

Kata kunci: berpikir kritis, materi suhu, pembelajaran virtual.

\section{- INTRODUCTION}

The rapid advancement of science and technology in the 21 st century requires students to have many thinking skills to face an increasingly competitive world and compete at the global level. (Fuad, et al 2017). The skills most closely related to learning are learning and innovation consisting of; (1) critical thinking and problem solving, (2) communication and collaboration, and (3) creativity and innovation (Daryanto, 2017). Student-centered learning activities are the goal of the demands of the 21 st century. This is in accordance with the points of perfecting the mindset of the 2013 curriculum contained in Permendikbud No. 68 of 2013 about the junior high school curriculum where

Aji Solehudin et al.

Email: ajisolehudin43@gmail.com
DOI: http://dx.doi.org/10.23960/jpmipa/v22i2.pp305-314

Received: 25 November 2021

Accepted: 29 December 2021 
the teacher-centered learning pattern becomes student-centered learning; one-way learning pattern (teacher-student interaction) into interactive learning (teacher-student interactive-community-natural environment, and other sources or media); isolated learning patterns into networked learning (students can gain knowledge from anyone and from anywhere); the pattern of passive learning becomes active-seeking learning (students' active seeking learning is further strengthened by the science approach learning model); self-study patterns into group learning (team-based); and passive learning patterns into critical learning (Minister of Education and Culture, 2013).

Mastery of 21 st century skills in schools is not only to build student knowledge, but is expected to improve critical thinking skills, communication, creativity, and collaboration. Critical thinking skills are starting to be noticed by the government and are considered important along with the needs of the 21 st century. So that critical thinking skills are starting to be applied in every school along with the 2013 curriculum (Minister of Education and Culture, 2017). Increasing high-level skills in junior high school is the right time because the cognitive development of adolescent students has matured so that they can be challenged to think more complexly. Practicing thinking skills can help students to become critical thinkers effectively in accordance with one of the objectives of the 2013 curriculum where students can have logical skills in solving a problem. (Mutakinati, Anwari \& Yoshisuke, 2018).

Science learning does not only pay attention to the achievement of the knowledge aspect, but also to the aspects of attitudes and skills through the process of observation and thinking logically, systematically, and critically based on the scientific process (Sanjaya) in (Hajar, 2019). Therefore, science learning should be formed in a scientific environment with a process of observation, investigation, and thinking logically and critically, how science knowledge in the form of theory is formed through students' critical thinking skills. Science material has the potential to develop students' critical thinking skills because science concepts are often found in everyday life, so teachers can teach students through meaningful learning activities that connect students' prior knowledge with new information that will be received. According to Jufriana \& Utami in (Danora, 2020) meaningful learning activities can develop students' critical thinking skills. This is of course in accordance with the demands of the 2013 curriculum that has been conveyed previously.

Practicing critical thinking skills is very important for the provision of students in developing their abilities to solve problems and explain phenomena that exist in everyday life (Erna, et al, 2018). Teachers who are actively involved in guiding students during learning will certainly have a positive impact on the development of students' critical thinking skills when students solve a problem (Fung, 2017). Teachers who want to develop students' critical thinking skills must master the concepts that will be taught to students, besides that teacher must guide students to analyze, ask questions, and find solutions to evaluate and develop their thinking skills (Cáceres, 2020). The importance of teaching critical thinking skills to students cannot be ignored because critical thinking skills are the basis that allows students to overcome and face increasingly complex life problems (Ratnasari, 2020).

Ennis (1985) divides the critical thinking skills group into 5 aspects of critical thinking: providing simple explanations (elementary clarification), building basic skills (basic support), drawing conclusions (inference), providing further explanation (advanced clarification), setting strategies and tactics (strategies and tactics). Each of these aspects is specifically made into several indicators of critical thinking skills 
including: (1) focusing on a question; (2) analyze arguments; (3) ask and answer classification or challenge questions; (4) consider the credibility of the source; (5) observe and consider the results of observations; (6) make deductions and consider the results of the deductions; (7) make an induction and consider the results of the induction; (8) make and consider the value of decisions; (9) define terms and consider definitions; (10) identify assumptions; (11) decide on an action; (12) interact with other people.

The results obtained from the analysis of three science lessons in West Java by Nusantara, Shibata \& Hendayana on (Hajar, 2019) showed that in general learning was still dominated by teacher explanations and short student answers simultaneously and students' dependence on teachers was so great in learning. This fact and statement is reinforced by the results of observations made by researchers in one of the junior high schools in Bandung district on some teachers in science learning class VII through interviews, that learning with conventional discussion methods (lectures and questions and answers) is still in demand by teachers because they are still assume that this method is the easiest method to implement, can save time because it does not require excessive preparation. The limited time for virtual learning is also an obstacle in addition to other obstacles such as the internet network, the condition of each student's gadget will also interfere with ongoing virtual learning activities.

According to Burrowes in (Danora, et al, 2020) conventional learning only emphasizes content recitation, without giving students sufficient time to reflect on the material presented, relate it to prior knowledge, or apply it to real-life situations. Based on the problems above, the researchers conducted a case study that aims to find out how students' critical thinking skills in virtual learning use the free version of the media zoom meeting with lecture and question and answer methods.

\section{- METHOD}

This research is descriptive research by applying case studies. This method was chosen because the researcher wanted to describe students' critical thinking skills during the virtual learning process. The research was conducted by observing virtual science learning on 31 students of seventh class grade through a zoom meeting platform on temperature topic in one of the junior high schools in Bandung, West Java, Indonesia on the first semester of the 2020/2021 academic year. The research data was in the form of learning transcripts which were collected through observation. Analysis of learning is done after observation using Transcript Based Lesson Analysis (TBLA). TBLA aims to determine the characteristics of learning (Arani, 2017). Transcript analysis is an important method for studying classroom learning, both online and offline (Van Booven, 2015). Transcription and recording systems using video and camcorders allow TBLA to be a solution when direct observation of learning in the classroom is not possible due to various factors, such as schools in remote areas or the pandemic currently happening. Communication in learning, both synchronous and asynchronous, can be transcribed, and data are analysed using the TBLA method (Winarti, 2021). Students' critical thinking skills during learning were analyzed using TBLA which was identified from critical thinking skills indicators according to Ennis (1985).

\section{- RESULT AND DISCUSSION}

\section{Virtual Learning on Temperature Topic in Junior High School}

Virtual learning is carried out using zoom meeting media with a duration of about 40 minutes. Based on observations, the learning process carried out by the teacher was 
informative and sufficiently motivated students to be actively involved in learning. In the preliminary activity the teacher conveys the learning objectives and relates the learning to be carried out with the Student Activity Sheet or (LKPD) that has been given previously. In the Student Activity Sheet (LKPD), there are some simple activities that every student must do at home. To stimulate students' memories, the teacher conducts discussions related to activities that have been carried out by students at home by asking and answering the same questions as in Student Activity Sheet (LKPD). Students are asked to turn on the microphone and say their names and answer any questions from the teacher related to activities that have been done at home.

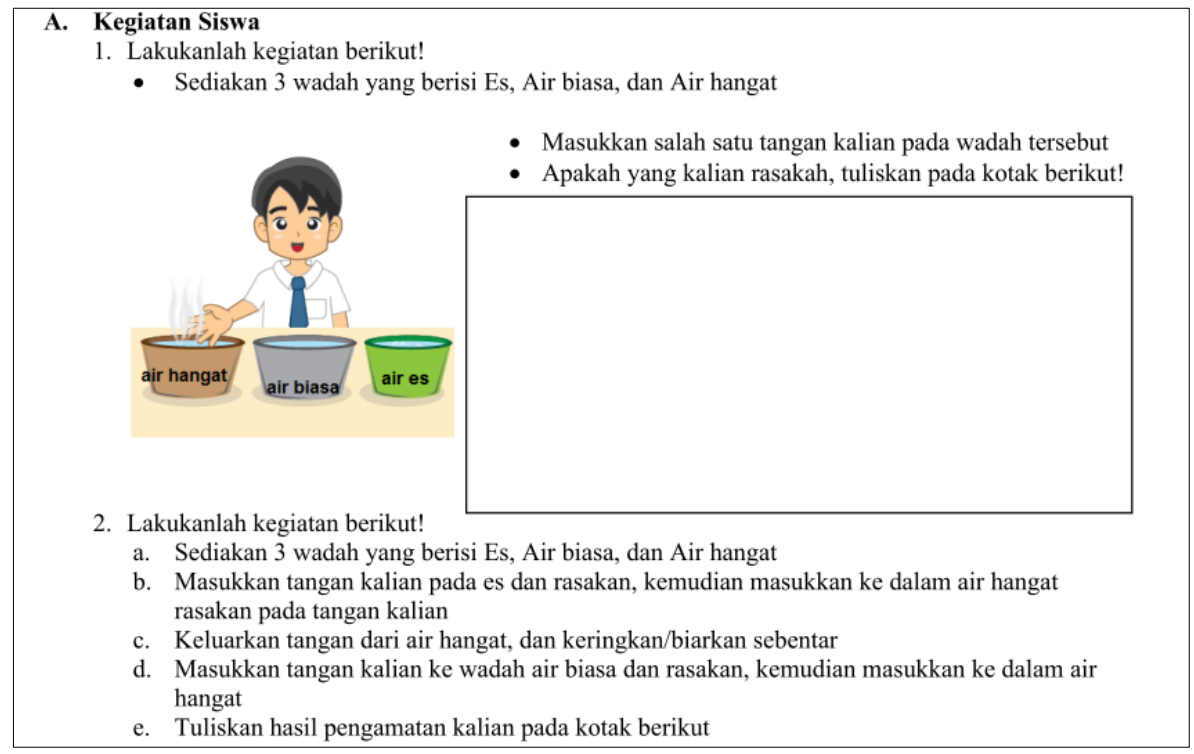

Gambar 1. Activities on student activity sheet that every student must do at home

In the core activity the teacher focuses on learning by dividing it into four stages. The first stage begins with the teacher discussing with students about a temperature measuring device in the form of a thermometer. In the second stage, the teacher explains and asks about various types of thermometers. The third stage the teacher explains and asks about the comparison of the scales on each thermometer. The last stage the teacher explains to students about how to calculate the scale comparison on each thermometer. Each stage is carried out by delivering information and questions to students. However, due to the limited time of use of the virtual learning media used, the teacher only explains the main points, not too much detail and the explanation from the teacher dominates in the last stage compared to asking and discussing with students as in the previous stage. 


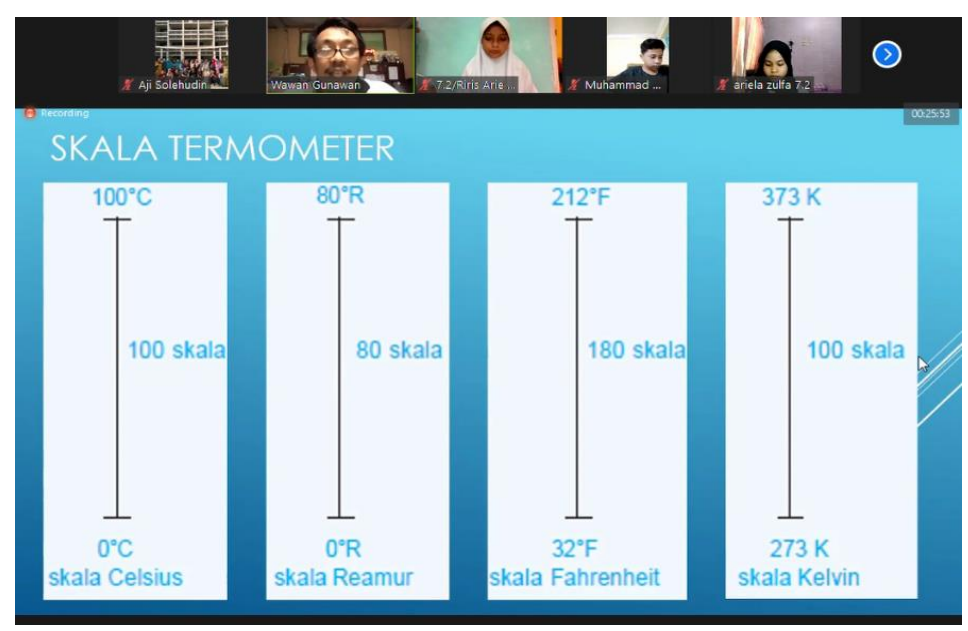

Gambar 2. The teacher is explaining the thermometer scale to students

The process of learning is enough to motivate students by encouraging students to actively ask questions. However, due to the limited time the use of the virtual learning media used is limited, the learning seems rushed and the teacher's focus is often distracted by the limited time, the learning becomes one-way, the teacher is more active in conveying knowledge material in the form of explanations. There were some students who looked sleepy and could not understand what the teacher was saying. Students seem inclined to accept and justify the teacher's words without daring to express and interpret their thoughts. This is in accordance with Asmuni's opinion in (Zakaria, 2021) which reveals that the obstacle when learning virtual is that the content of the material delivered virtual may not necessarily be understood by all students due to the limitations of the teacher in controlling learning. As well as the opinion expressed by (Huang et al., 2020) which states that teachers have not prepared their learning content to adapt to virtual learning, and preparing such content will take time. In addition, students also need more effort to understand the material that is usually delivered orally then now becomes written and video.

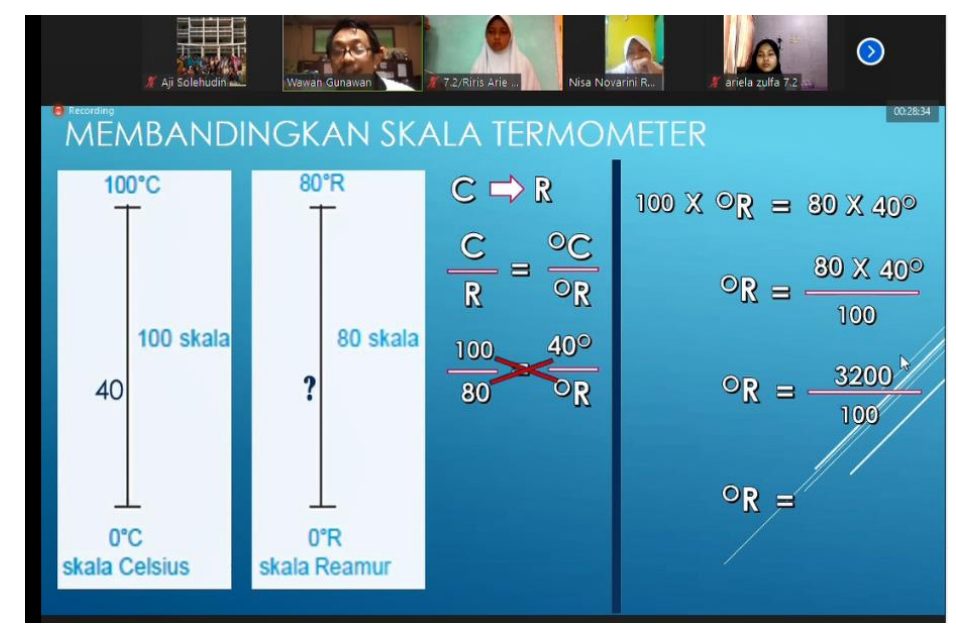

Gambar 3. The teacher is explaining the formula for comparing the thermometer scale to students

At the time of virtual learning students are not directly involved in solving problems through certain phenomena related to the concept of science. Overall, the learning process 
carried out did not provide opportunities for students to think critically in solving problems related to the concepts being studied. Every student should be faced with a deep problem structure, because most students' thinking tends to be concentrated on the surface structure of the problem (Bunt \& Gouws, 2020). Optimal virtual learning will make students' critical thinking skills even more optimal (Solikhin, 2021).

\section{Students' Critical Thinking Skills During the Virtual Learning Process}

The results of the analysis of students' critical thinking skills are based on Transcript Based Lesson Analysis (TBLA) which refers to the indicators and sub-indicators of critical thinking skills according to Ennis (1985). During the learning process, it was revealed that only two of the twelve indicators of students' critical thinking skills occurred. The two indicators are described as follows.

\section{Focusing on a question}

The sub-indicator that emerges from the "focusing on a question" indicator is subindicator $1 \mathrm{~b}$. namely identifying or formulating criteria for considering possible answers. This sub-indicator often appears during learning when the teacher gives questions to students. Students identify questions from the teacher then answer questions from the teacher. However, questions from teachers sometimes lead to answers from students which are textbooks, meaning that the answers are almost the same as textbooks. Students do not explore the answers on their own and still rely on the source books they have. This can be seen in the following transcript.

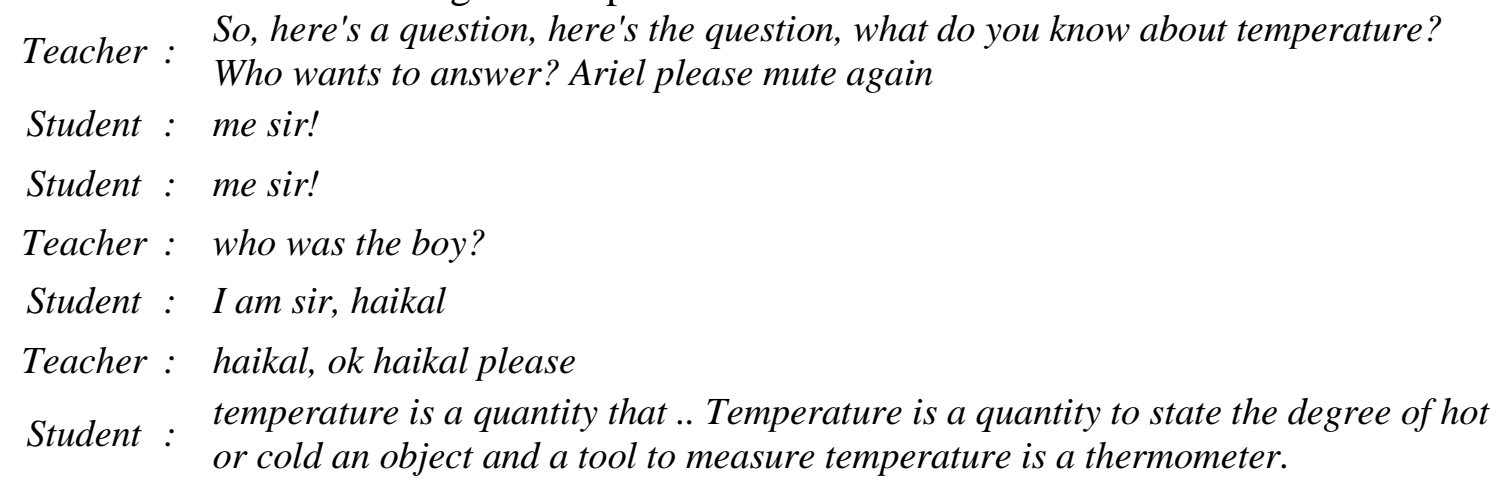

The types of questions presented by the teacher in virtual learning are still at the low-level thinking level (LOTS), namely "remembering". In addition, the questions are more likely to be authoritative, where there is only one correct answer. Authoritative questions can limit students' opportunities to demonstrate a high level of understanding. On the other hand, dialogical questions often provide discursive space for students to show broader and deeper knowledge (Chin; Zhang \& Patrick) on (Winarti, 2021).

\section{Ask and answer classification or challenge questions}

The sub-indicators that emerge from the "ask and answer classification or challenge questions" are sub-indicators $3 \mathrm{c}$, namely why and sub-indicators $3 \mathrm{j}$, namely what are the facts. Sub-indicator 3c "why" appears when students answer the question "why" which shows the emergence of critical thinking skills. In this lesson, the teacher asks students whether the hand that feels cold and warm water can be used to determine the temperature, then one of the students gives a short answer "no" this makes the teacher ask an additional question "why not?" to the student. This can be seen from the following transcript. 


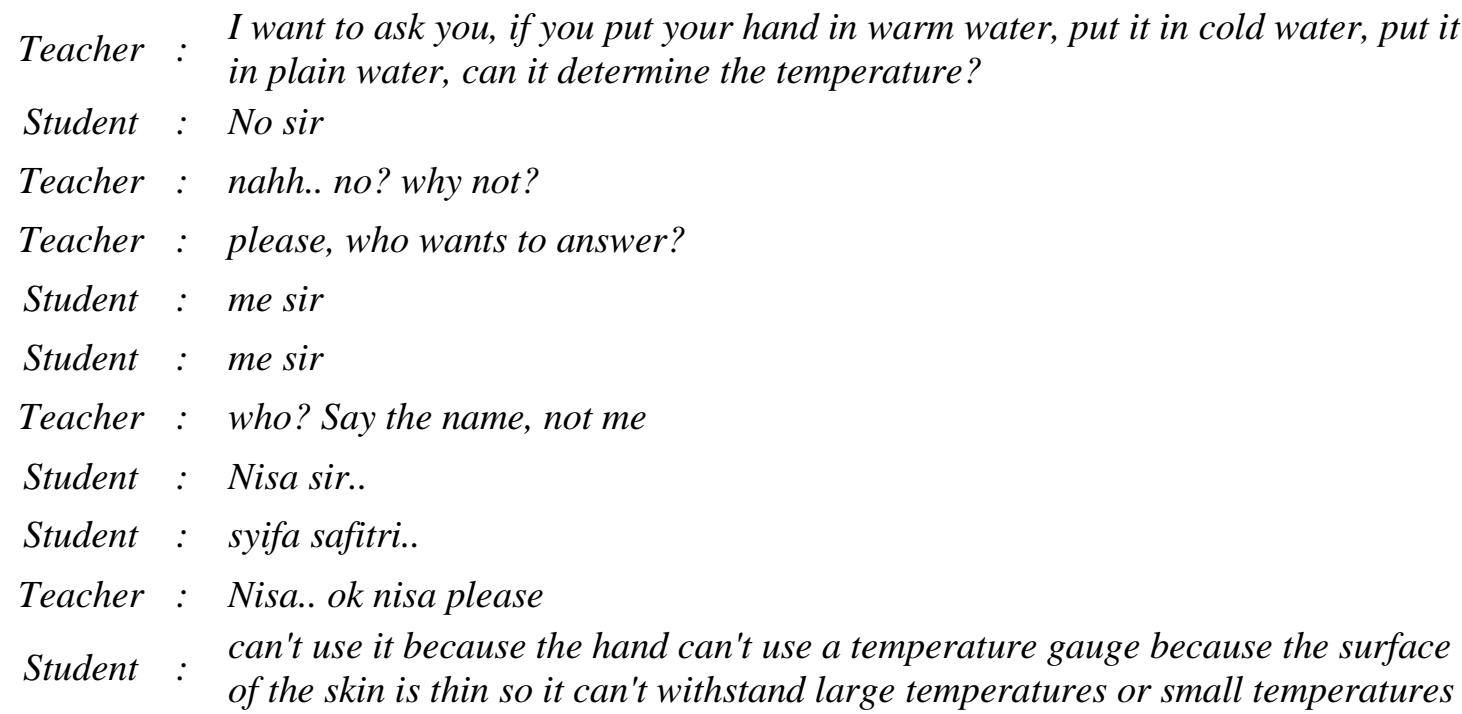

The question of "why" category can develop into a source of inquiry processes and critical thinking development. This student-centered pattern supports the provision of feedback used by teachers to get students to engage in deep learning (Winarti, 2021). According to (Janah, 2018) teachers who ask divergent questions such as "How...", "Why..." and ask further questions can strengthen concepts. Therefore, the questions shown from the transcript can build answers that require students to think critically. Subindicator $3 \mathrm{j}$ "what are the facts" appears when the teacher asks about students' experiences regarding using thermometers in everyday life. Students answered "at the mall" then the teacher asked again related to how to use it and students answered "shot in the forehead" immediately. This shows that students' critical thinking skills are seen when answering questions from the teacher based on the "facts" they see in their daily lives. This can be seen from the following transcript.

\author{
Teacher: I want to know about your experience, where is the most widely used thermometer at
this time? \\ Student : at mall \\ Teacher: at mall, okay what is used like what? \\ Student : shot in the forehead (pointing hand to forehead)
}

Questions with the "what" category are often asked by teachers throughout the lesson from the beginning of learning to the end of learning. This causes students' answers to be concise. Furthermore, observations during the learning process and data from several research results show that in the science class, asking questions is the most important activity (Biggers, 2018). However, not all teacher questions can motivate students to carry out scientific investigations. The types of questions that are often asked by teachers are mostly at the "remember" and "understand" level or still at the LOTS level. Furthermore, more questions were asked by teachers, not by students (Biggers, 2018; Matra, 2014).

The teacher's questioning skill is a fundamental problem in this research. As long as the questions are only at the lower level of thinking, the teacher will have difficulty evaluating student achievement, and their thinking skills will not develop. However, when questions are more inquiry-based, communication between students can be more intensive, and their critical thinking skills can be further developed (Taat et al., 2020). 
In the virtual learning, students are active, but have no motivation to find concepts independently is not developed. Even, many studies have shown that problem-solving learning involving higher-order thinking skill level can improve students' critical thinking (Amin et al., 2020). Meanwhile, learning designs with more student-centered, such as collaboration, managing an effective relationship between teacher-students and studentsstudents, enable students to share ideas, convey reasons and reflect on an understanding of the learning topic through various strategies and make their communication skills better (Bature \& Atweh, 2019).

\section{- CONCLUSION}

Based on the results of the analysis and discussion of the data, it can be concluded that two of the twelve indicators of critical thinking skills have been achieved in science virtual learning on the subject of Temperature in Junior High School. The two indicators are focusing on a question and asking and answering classification or challenge questions. The low achievement of indicators for students' critical thinking skills is due to the limited time to use virtual learning media which is limited so that teachers often apply learning methods that are only in the form of transferring knowledge from teachers to students without giving enough time to students to provide conclusions from the material that has been delivered. The results of this study also show that students' critical thinking skills can not only be analyzed based on the results of the pre-test and post-test but can also be seen from the students' activities and dialogues that appear during the learning process, especially during virtual learning. Analysis of student activities and dialogue with students or students with teachers during virtual learning is needed not only to analyze student skills or activities but can also be used as reflection material for teachers to evaluate and improve further learning to make it even better. However, facilities in virtual learning must also be considered such as the selection of virtual learning media that is not limited by time and the readiness of the internet network owned by teachers and students must be good and as a comparison, further research is needed that measures students' critical thinking skills in virtual learning based on the results. pre-test and post-test. Hopefully this research can be the basis for further research to improve virtual learning better.

\section{- REFERENCES}

Amin, S., Sumarmi, S., Bachri, S., Susilo, S., \& Bashith, A. (2020). The effect of problem-based hybrid learning (PBHL) models on spatial thinking ability and geography learning outcomes. International Journal of Emerging Technologies in Learning, 15(19), 83-94.

Arani, M. R. S. (2017). Raising the quality of teaching through kyouzai kenkyuu-the study of teaching materials. International Journal for Lesson and Learning Studies, 6(1), 10-26.

Bature, I. J., \& Atweh, B. (2019). Collaboration: A collective bargain for achieving quality mathematics classroom practice. International Journal of Educational Methodology, 5(3), 347-361.

Biggers, M. (2018). Questioning questions: elementary teachers' adaptations of investigation questions across the inquiry continuum. Research in Science Education, 48(1), 1-28. 
Bunt, B., \& Gouws, G. (2020). Using an artificial life simulation to enhance reflective critical thinking among student teachers. Smart Learning Environments, 7(12), 119.

Cáceres, Martín, Miguel Nussbaum, and Jorge Ortiz. (2020). "Integrating Critical Thinking into the Classroom: A Teacher's Perspective." Thinking Skills and Creativity Vol. 37:100674.

Danora, Y., Hendayana, S., \& Supriatnam, A. (2020). The Students' Critical Thinking Skill in Exploiting Covalent Bond Material. Journal of Educational Sciences, 4(3), 478-486.

Danora, Y. (2020). Pengembangan Lesson Design Sharing \& Jumping Task untuk Menumbuhkan Aktivitas Keterampilan Berpikir Kritis Siswa pada Pembelajaran Reaksi Redoks [Development of Lesson Design Sharing and Jumping Tasks to Grow Students' Critical Thinking Skills Activities in Redox Reaction Learning] (Thesis). Retrieved from http://repository.upi.edu/

Daryanto dan Karim, S. (2017). Pembelajaran Abad 21 [21st Century Learning]. Yogyakarta: Gaya Media.

Ennis, R. H. (1985). A logical basis for measuring critical thinking skills.

Erna, M., Rery, R., Astuti, W., \& Sulismayati. (2018). Peningkatan Kemampuan Berpikir Kritis Peserta Didik pada Materi Termokimia di SMA Pekanbaru melalui Penerapan Strategi Pembelajaran Process Oriented Guided Inquiry Learning (POGIL) [Improving Students' Critical Thinking Skills on Thermochemical Materials at SMA Pekanbaru through the Implementation of Process Oriented Guided Inquiry Learning (POGIL) Learning Strategies]. Jurnal Riset Pendidikan Kimia, 8(1), 17-27.

Fuad, N. M., et.al. (2017). Improving Junior High Schools' Critical Thinking Skills Based on Test Three Different Models of Learning. International Journal of Instruction. Vol. 10 (1), 101-116.

Fung, Dennis. (2017). “The Pedagogical Impacts on Students' Development of Critical Thinking Dispositions: Experience from Hong Kong Secondary Schools.” Thinking Skills and Creativity Vol. 26, 128-39.

Hajar, Maya Umi. (2019). Analisis Pola Dialog Pembelajaran IPA Menggunakan TBLA (Transcript Based Lesson Analysis) di Salah Satu SMP Kota Bandung [Analysis of Dialogue Patterns in Science Learning Using TBLA (Transcript Based Lesson Analysis) in one of the junior high schools in Bandung] (Thesis). Retrieved from http://repository.upi.edu/

Huang, R., Tlili, A., Chang, T., Zhang, X., Nascimbeni, F., \& Burgos, D. (2020). Disrupted classes, undisrupted learning during COVID-19 outbreak in China: application of open educational practices and resources. Smart Learning Environments, 7(19), 1-15.

Janah, N., Nahadi., S, Hendayana., S, Tresnasih (2019). Using transcript-based lesson analysis to determine teacher discourse move in science lesson. J. Phys.: Conf. Ser. 1157022062.

Matra, S. D. (2014). Teacher questioning in classroom interaction. A Journal of Culture, English Language Teaching \& Literature, 14(1), 82-111.

Minister of Education and Culture. (2013). Peraturan Menteri Pendidikan dan Kebudayaan Nomor 68 Tahun 2013 tentang Kerangka Dasar dan Struktur Kurikulum Sekolah Menengah Pertama/Madrasah Tsanawiyah [Regulation of the Minister of Education and Culture Number 68 of 2013 concerning the Basic 
Framework and Curriculum Structure of Junior High Schools/Madrasah Tsanawiyah]. Jakarta: Menteri Pendidikan Dan Kebudayaan. Retrieved 10 January 2021 from https://simpuh.kemenag.go.id/regulasi/permendikbud_68_13.pdf

Minister of Education and Culture. (2017). Panduan Implementasi Kecakapan Abad 21 Kurikulum 2013 Di Sekolah Menengah Atas [Guidelines for Implementing 21st Century Skills 2013 Curriculum in High Schools]. Menteri Pendidikan dan Kebudayaan, 1-42. Retrieved 10 January 2021 from https://awan965.files.wordpress.com/2017/09/panduan-implementasi-kecakapanabad-21.pdf

Mutakinati, Lely, Ilman Anwari, and Kumano Yoshisuke. 2018. "Analysis of Students' Critical Thinking Skill of Middle School through Stem Education Project-Based Learning." Jurnal Pendidikan IPA Indonesia, 7(1):54-65.

Ratnasari, Supriatna, A, \& Hendayana, S. (2020). Critical Thinking Development in Collaborative Learning : Case study of Transformer Topic through Lesson Study at Junior High School, ICEIT:50-54.

Solikhin, M., \& Fauziah, A.N.M. (2021). Analisis kemampuan berpikir kritis siswa SMP pada pelajaran IPA saat pembelajaran daring selama pandemi COVID-19 [Analysis of the critical thinking skills of junior high school students in science lessons during online learning during the COVID-19 pandemic]. Pensa E-Jurnal: Pendidikan Sains, 9(2). 89-93.

Taat, M. S., Abdulbaki, K., \& Al-Saqqaf, A. (2020). The impact of lecture and interactive methods on student's English competency. International Journal of Emerging Tech-nologies in Learning, 15(20), 255-267.

Van Booven, C. D. (2015). Revisiting the authoritative-dialogic tension in inquiry-based elementary science teacher questioning. International Journal of Science Education, 37(8), 1182-1201.

Winarti, A., Saadi, P., \& Rajiani, I. (2021). Applying transcript-based lesson analysis in enhancing communication pattern between teacher and students in chemistry classroom. European Journal of Educational Research, 10(2), 975-987.

Zakaria, Perry., Nurwan., Silalahi, Frendy Dermawan. (2021). Deskripsi Kemampuan Berpikir Kritis Siswa Melalui Pembelajaran Daring pada Materi Segi Empat [Description of Students' Critical Thinking Ability Through Online Learning on Quadrangle Materials]. EULER:Jurnal Ilmiah Matematika, Sains dan Teknologi Vol. 9, 32-39. 